\title{
Assessment of Microbial Communities and Their Relationship with Enzymatic Activity during Composting
}

\author{
Khoshrooz Kazemi, Baiyu Zhang*, Leonard M. Lye \\ Faculty of Engineering and Applied Science, Memorial University of Newfoundland, St. John's, Canada \\ Email:k.kazemi@mun.ca, ^bzhang@mun.ca, llye@mun.ca
}

How to cite this paper: Kazemi, K., Zhang, B.Y. and Lye, L.M. (2017) Assessment of Microbial Communities and Their Relationship with Enzymatic Activity during Composting. World Journal of Engineering and Technology, 5, 93-102.

https://doi.org/10.4236/wjet.2017.53B011

Received: June 15, 2017

Accepted: August 8, 2017

Published: August 11, 2017

\begin{abstract}
Microbial communities and enzyme activities are the main players during municipal solid waste (MSW) composting, but the relationship between microbial communities (i.e., mesophilic and thermophilic ones) and enzyme activities (i.e., dehydrogenase, $\beta$-glucosidase, phosphatase and urea) has not been well studied. Therefore, the objective of this work is to determine the enzymes profiles during municipal solid waste (MSW) composting and study the relationship between the mesophilic and thermophilic microbial profiles and enzyme activities. MSW was composted in a bench-scale composting reactor. Parameters including temperature, oxygen uptake rate, numbers of microbial populations (mesophilic and thermophilic bacteria and fungi) and enzyme activities were measured. Results showed higher dehydrogenase activities are related to higher numbers of mesophilic bacteria, while higher phosphatase and urea activities are associated with higher numbers of thermophilic fungi and mesophilic bacteria at the later stage of composting. In addition, results of the correlation analysis indicated significant correlations among enzyme activities and microbial population.
\end{abstract}

\section{Keywords \\ Composting, Microbial Population, Enzyme Activity, Correlation Analysis}

\section{Introduction}

Among the many alternatives for the disposal of organic wastes, composting is one of the most attractive options due to its low environmental impact and cost, as well as its capacity for generating a valuable product used for increasing soil 
fertility [1]. Composting proceeds through three phases: the mesophilic phase $\left(10^{\circ} \mathrm{C}-42^{\circ} \mathrm{C}\right)$, the thermophilic $\left(45^{\circ} \mathrm{C}-70^{\circ} \mathrm{C}\right)$ or high-temperature phase which can last from a few days to several months, and finally, the maturation phase which may take several months of cooling [2]. Throughout the composting process, different microbial communities follow one another according to the nutritional and environmental conditions prevailing at each phase [1]. Microbial activity is achieved through the action of the enzymes that are responsible for the hydrolysis of the organic matter. The enzymes released by the microorganisms during composting break down several organic matter characterized by a complex structure, finally leading to the solubilisation of simple water soluble compounds [3]. As a consequence, enzymatic activities give information on the rate of decomposition of organic matter and, therefore, on product stability [1] [4]. Important enzymes involved in the composting process include dehydrogenase which reflects microbial activity, B-glucosidases which hydrolyze glucosides, urease involved in $\mathrm{N}$-mineralization, and phosphatases that remove phosphate and sulfate groups from organic matter [3] [4]. Characterizing microbial communities along the process is important for achieving the effective management of a composting process and it may provide valuable information regarding process evolution and biodegradation rate [5] [6]. The investigation of the significant enzymes (e.g., dehydrogenases, $\beta$-glucosidases, phosphodiesterase and ureases) provides data for a correct estimation of the events that take place throughout the composting process [7].

Although several researchers [1] [3] [8] have studied the dynamics of the microbial communities, little is known about the relationship between microbial diversity and enzyme activities during composting of the organic fraction of municipal solid waste (MSW). The present work thus aims at constructing a fuller picture of the microbial and enzyme activities in a small-scale composting system.

\section{Material and Methods}

\subsection{Composting Systems}

A composting reactor $(50 \times 20 \times 25 \mathrm{~cm})$ made of acrylic sheets was designed and manufactured for the experiment. Mixers were installed to enable homogenous mixing of materials. A perforated plate was installed over the bottom of the reactor to distribute the injected air. The aeration rate was monitored by a flowmeter (Acrylic block flowmeter, FR2000, VWR). The exhaust gas was discharged into a flask containing $\mathrm{H} 2 \mathrm{SO} 4$ solution $(1 \mathrm{M})$ to absorb $\mathrm{NH} 3$, and monitored by a gas monitoring system, then treated and released through a ventilation system. The leachate outlet was used to collect the outcome leachate. A thermometer was used to monitor the temperature. Insulation material used to prevent heat loss through the reactor walls. The schematic diagram of the composting system is presented in Figure 1.

Synthetic MSW (food waste) consisting of potato, carrot, meat, rice, cabbage, soybean, and bulking agent (peat) were mixed in a ratio to obtain a $\mathrm{C} / \mathrm{N}$ ratio of 
17 and moisture content of $70 \%$.

After turning, approximately $100 \mathrm{~g}$ compost was collected randomly from the composting system on the $2 \mathrm{nd}, 4 \mathrm{th}, 6 \mathrm{th}, 8 \mathrm{th}, 10 \mathrm{th}, 12 \mathrm{th}, 16 \mathrm{th}, 20 \mathrm{th}$, and $27 \mathrm{th}$ day. The collected samples were divided into different sub-samples to measure enzyme activities and count microbial colony. Temperature and oxygen uptake rate (OUR) were recorded every 12 hours. Data for microbial populations and enzyme activities were reported as the averages of at least three replicates.

\subsection{Analytical Methods}

Temperature was recorded by a bi-metal dial thermometer (H-B Instrument Company, PA). The outlet oxygen concentration in the compost exhaust gas was monitored by passing the air through a multi-Gas Monitor (M40 Industrial Scientific Corp., Oakdale, PA, USA). OUR was calculated using the following equation:

$$
\text { OUR }=\left(\mathrm{O}_{2} \text { out }(\%)-\mathrm{O}_{2} \text { in }(\%)\right) \times \text { airflow rate }(L / \mathrm{min})
$$

where $\mathrm{O}_{2}$ out (\%) is the oxygen concentration in compost exhaust gas and $\mathrm{O}_{2}$ in (\%) is the oxygen concentration in the inlet air $(20.9 \%)$ at airflow rate $(0.5$ $\mathrm{L} / \mathrm{min} / \mathrm{kg}$ ) which is injected to the system.

Dehydrogenase activity determination, was based on the estimation of the triphenyltetrazolium chloride (TTC) reduction rate to triphenyl formazan. $5 \mathrm{~g}$ sample was suspended in $5 \mathrm{~mL}$ of $3 \% \mathrm{w} / \mathrm{v} 2,3,5$-triphenyl-tetrazolium chloride (TTC) at $37^{\circ} \mathrm{C}$ for $24 \mathrm{~h}$ in the dark, and then $40 \mathrm{~mL}$ acetone was added and incubated at room temperature for $2 \mathrm{~h}$ in the dark. The suspension was filtered through a glass fiber filter and absorbance was measured at $546 \mathrm{~nm}$ [9] [10]. $\beta$ glucosidase activity measurement was based on determining the quantity of the released p-nitrophenol after the incubation of compost samples with p-nitrophenyl glucoside (PNG) solution for $1 \mathrm{~h}$ at $37^{\circ} \mathrm{C} .1 \mathrm{~g}$ sample was suspended in $0.25 \mathrm{~mL}$ toluene and $4 \mathrm{~mL}$ of MUB (Modified Universal Buffer, $\mathrm{pH}$ 6.0) plus 1 $\mathrm{mL}$-nitropenyl- $\beta$-D-glucopyranoside (Sigma; for glucosidase). After incubation for $1 \mathrm{~h}$ at $37^{\circ} \mathrm{C}, 1 \mathrm{~mL}$ of $0.5 \mathrm{M} \mathrm{CaCl} 2$ and $4 \mathrm{~mL}$ Tris buffer (0.1 M, pH 12) were added and the suspension was filtered through a glass fiber filter. The re-

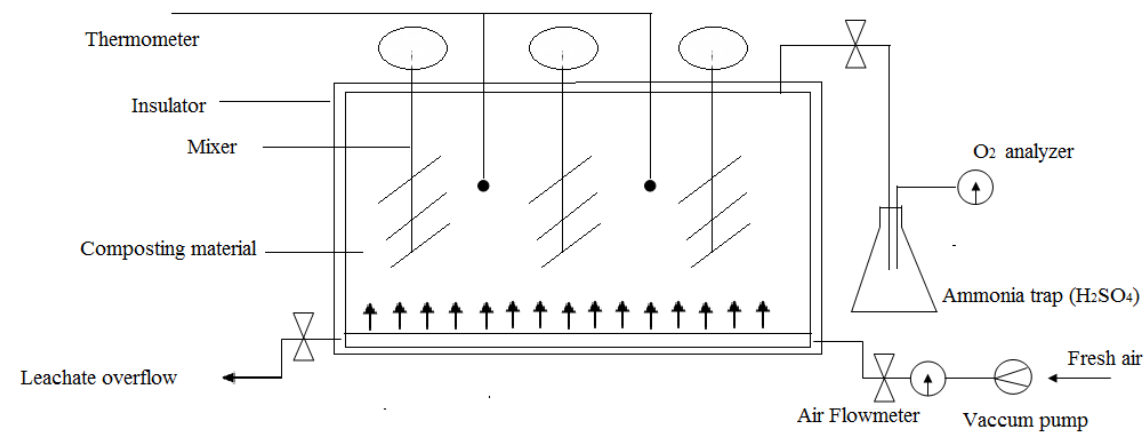

Figure 1. Schematic diagram of the composting system. 
lease of p-nitrophenol was measured spectrophotometrically at $400 \mathrm{~nm}$ [10] [11]. The same reaction was used for the determination of the Phosphodiesterase activity, with the substitution of the PNG by bis-p-nitrophenyl phosphate. After the addition of a Tris buffer ( $\mathrm{pH}$ 8) and bis-p-nitrophenyl phosphate to $1 \mathrm{~g}$ compost, samples were incubated for $1 \mathrm{~h}$ at $37^{\circ} \mathrm{C}$. The p-nitrophenol released by bis-p-nitrophenyl phosphate was extracted and coloured with calcium chloride and determined spectrophotometrically at $400 \mathrm{~nm}$ [12]. Urease activity assay was based on determination of ammonia release after the incubation of samples with urea solutions. $5 \mathrm{~g}$ sample were mixed with $2.5 \mathrm{ml}$ urea solution and incubated for $2 \mathrm{~h}$ at $37^{\circ} \mathrm{C}$. After incubation $50 \mathrm{ml} \mathrm{KCL}$ solution were added to the solution. The suspension was filtered through a glass fiber filter and analyzed for ammonium content.

\subsection{Microorganism Colony Counting}

Spread plate counting method was used to count the number of microorganism colonies [5]. The culture medium for total thermophilic and mesophilic bacteria was $10 \%$ strength tryptic soy broth agar. Potato dextrose agar supplemented with lactic acid was selective medium to culture fungi. For each test, $10 \mathrm{~g}$ (fresh weight) of sample was added into a $250 \mathrm{ml}$ Erlenmeyer flask with $90 \mathrm{ml}$ of $0.85 \%$ sterile sodium chloride solution, then was shaken at $200 \mathrm{rpm}$ for $30 \mathrm{~min}$ at $20 \pm$ $1^{\circ} \mathrm{C}$. Supernatant was diluted with $0.85 \%$ sterilized sodium chloride solution to prepare tenfold serial dilutions ranged from $10-2$ to $10-10$. The plate for mesophilic bacteria and fungi and thermophilic bacteria and fungi were incubated at $25^{\circ} \mathrm{C}$ and $55^{\circ} \mathrm{C}$, respectively. The incubation durations were 7 days for mesophilic bacteria and fungi and 2 days for thermophilic bacteria and fungi. The numbers were expressed as colony forming units (CFU) per dry weight of composts.

$$
\begin{aligned}
& \log _{10} \text { colony count } \\
& =\log _{10}\left(\frac{\text { Number of Colony }}{i} \times \text { Dilution factor } \times 100_{1-\text { Moisture content }_{i}}\right) C F U / g \text { dry sample }
\end{aligned}
$$

\section{Results and Discussion}

\subsection{Temperature and OUR}

Temperature rises due to metabolic heat production from biodegradation during composting [13]. Temperature measurements within the composting matrix give an indication of the establishment of ideal conditions that support microbial degradation [2]. As shown in Figure 2, temperature increased after 2 days and stayed above $55^{\circ} \mathrm{C}$ for more than 6 days, another peak was observed after 10 days and then it started to drop gradually and reached ambient temperature after three weeks. Respiration rate is higher in the presence of large amounts of bioavailable organic matter for microorganisms while it is slower if this type of material is scarce [14]. OUR followed the same pattern as temperature. OUR was high during first and second week of composting. After the second week of 


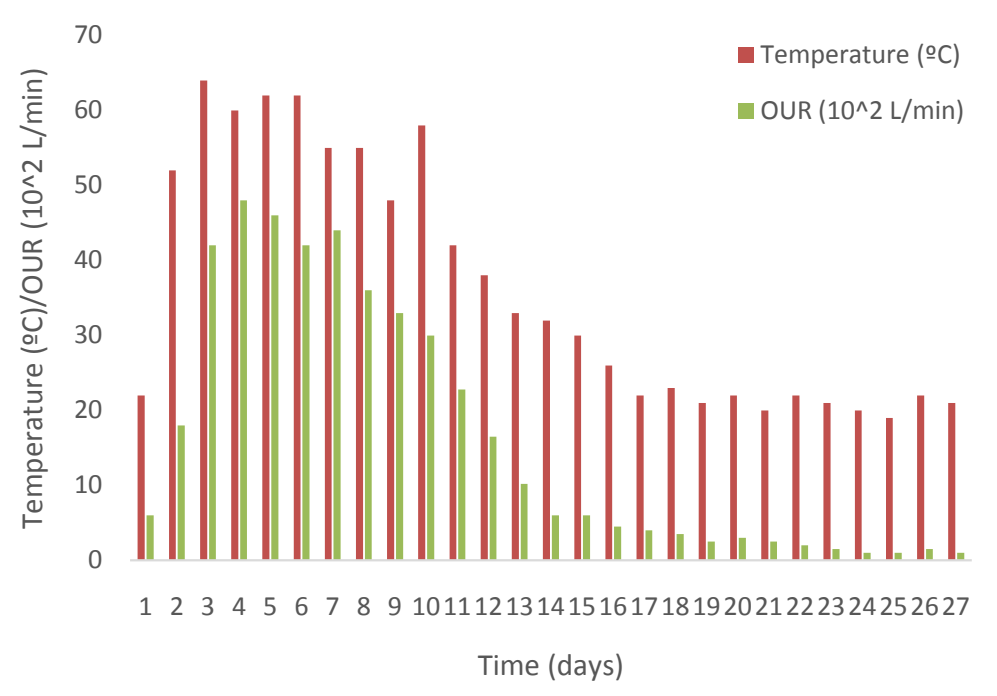

Figure 2. Temporal variations of Temperature and OUR during MSW composting.

composting, the reduction of biodegradable matter which cannot sustain high microbial activity caused a fall in OUR and it stayed constant by the end of composting.

\subsection{Microbial Population}

Microbial succession plays an important role during decomposition, acting as an indicator of the composting process. The appearance of specific microorganisms reflects the maturity of compost [2]. The succession of different microbial groups during composting is illustrated in Figure 3. Mesophilic bacteria were predominant at the beginning of the process. When the temperature rises, the number of mesophilic bacteria started to drop and stayed almost steady by the end of composting. At the early stage of the process, the presence of readily available carbon substrates, as well as the prevalence of mesophilic temperatures, favor high levels of microbial populations [1]. Populations of thermophilic bacteria increased gradually when temperature reached over $55^{\circ} \mathrm{C}$, and it peaked at day 4 , became stable between days 4 and 10 , and then decreased gradually until the end of the composting period. The results showed that the highest activity of the thermophilic bacteria was observed at $60^{\circ} \mathrm{C}$. As it is indicated by [15], the mesophiles which are abundant in the early phase of the process were the primary active degraders of the fresh organic waste, while thermophiles stimulated by the rapid increase of temperature occurring during the thermophilic phase, drove the degradation of more recalcitrant molecules such as lignocellulosic materials [15]. [16] also studied microbial succession during composting and reported that in the early stage of composting, thriving bacteria growth is responsible for the initial decomposition of organic matter and the generation of heat. Also, numbers of bacteria are usually higher than numbers of fungi due to the shorter time required for growth of bacteria than that of fungi [5].

The count of thermophilic fungi remained essentially constant and then suf- 


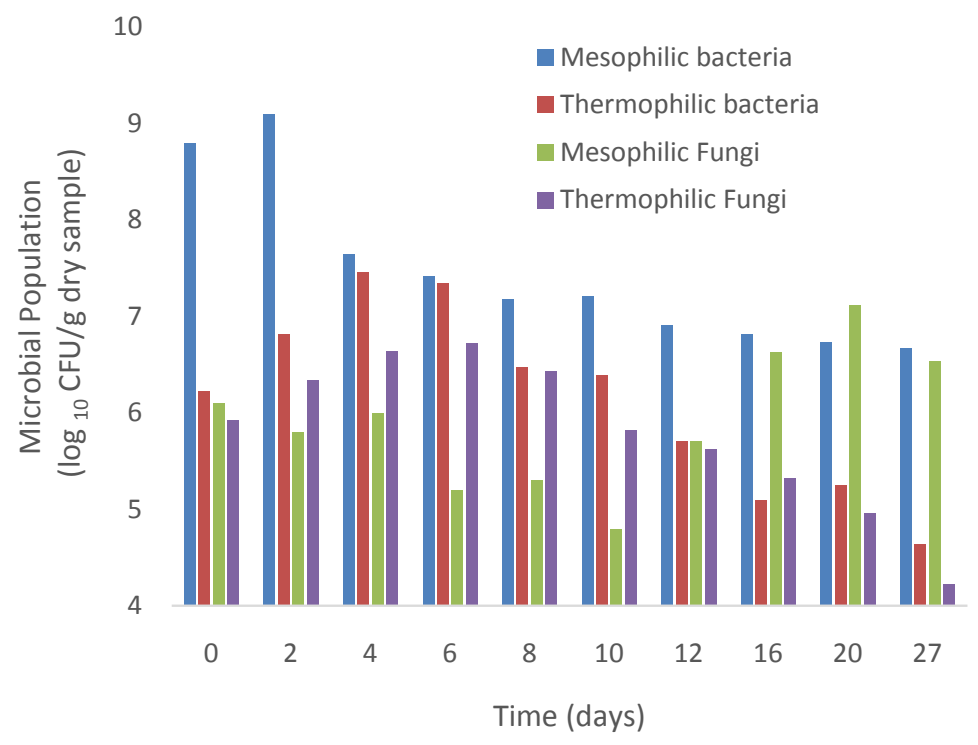

Figure 3. Microbial population counts during MSW composting processes.

fered a drop after 10 days whereas the mesophilic fungi population underwent an increase during the thermophilic period from day 4 to day 10 with the maximum at day 6. The mesophilic fungi population peaked again after three weeks of composting. The fungi benefit from the decrease in temperature, $\mathrm{pH}$ and moisture content that take place as the process evolves, therefore the count of mesophilic fungi population stayed high until the end of the experiment [17]. A population increase of mesophilic bacteria and fungi after the bio-oxidative cycle through the curing stage was recorded by [1]. In addition, to obtain a mature product and degrade the lignocellulose compound during the maturation phase, the presence of numerous microbial populations was crucial [5].

\subsection{Enzyme Activities}

It has been suggested that successful composting requires a level of interaction among microbial species. Microorganism-induced degradation of organic matter relies on the activity of various enzymes. The monitoring of enzyme activities throughout the compost process is informative with respect to understanding transformations that occurred during composting [18].

Enzyme activities in the compost depends on the available biodegradable matter and microbial activity at different stages of composting. Dehydrogenase activity is a measure of the intensity of microbial metabolism in compost and thus of microbial activity in compost [19]. Urease catalyzes the hydrolysis of urea to $\mathrm{CO} 2$ and $\mathrm{NH}^{4+}$ [20]. $\beta$-glucosidases are involved in the carbon cycle through the hydrolysis of glucosides, while phosphatases release phosphate groups from organic matter [1]. As shown in Figure 4, Phosphodiesterase and urease activities were high during the first 2 weeks of composting while dehydrogenase and $\beta$-Glucosidase activities were lower. The activity of all enzymes decreased by the end of composting. The highest cumulative enzyme activities 
were recorded for phosphodiesterase and then urease.

\subsection{Correlation Analysis}

As indicated in Figure 5, the relationships among the parameters are mostly not linear, as such the Spearman's correlation coefficient $(\rho)$ was used for testing the correlations between enzyme activities and microbial colony. The Spearman's rank correlations among the enzyme activities and microbial populations are shown in Table 1.

Although [20] found a high correlation between the hydrolytic enzyme activi

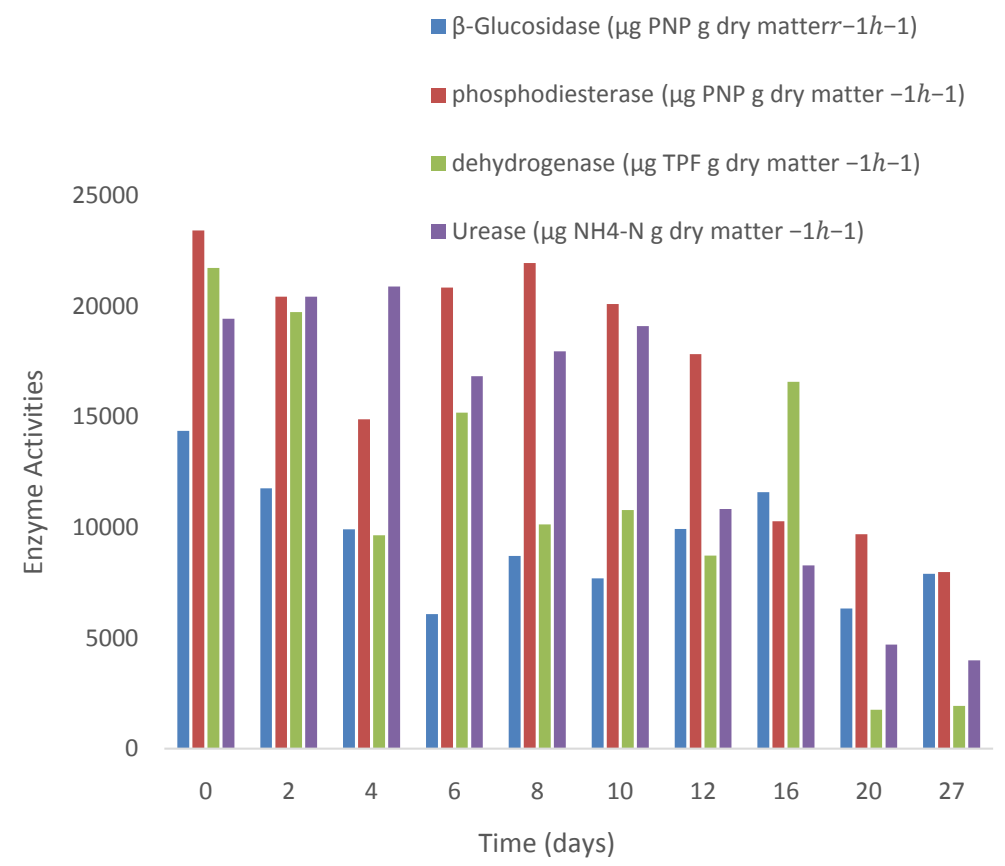

Figure 4. $\beta$-glucosidase, phosphodiesterase, dehydrogenase and urease activity during MSW waste composting.

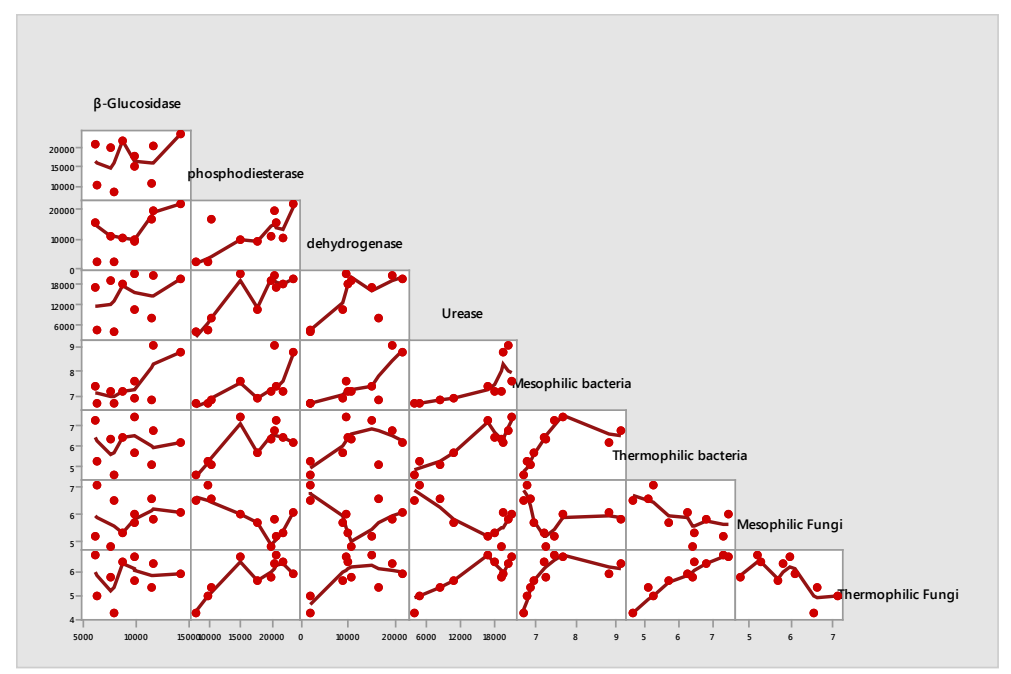

Figure 5. Correlation matrix plot of variables with lowess fit line. 
Table 1. Spearman's correlation matrix between $\beta$-glucosidase, phosphodiesterase, dehydrogenase, urease, mesophilic bacteria, thermophilic bacteria, mesophilic fungi and thermophilic fungi during MSW composting.

\begin{tabular}{ccccc}
\hline & $\beta$-Glucosidase & Phosphodiesterase & Dehydrogenase & Urease \\
\hline Phosphodiesterase & 0.273 & & & \\
Dehydrogenase & 0.576 & $0.685^{*}$ & & \\
Urease & 0.418 & 0.612 & 0.552 & \\
Mesophilic Bacteria & 0.43 & $0.733^{*}$ & $0.721^{*}$ & $0.927^{\star}$ \\
Thermophilic Bacteria & -0.055 & 0.576 & 0.321 & $0.818^{*}$ \\
Mesophilic Fungi & 0.248 & -0.6 & -0.244 & -0.43 \\
Thermophilic Fungi & -0.006 & $0.709^{*}$ & 0.442 & $0.745^{*}$ \\
\hline
\end{tabular}

${ }^{*}$ Correlation is significant at the 0.05 level.

ties and the dehydrogenase activity, in the present composting experiment, only the phosphodiesterase activity had a positive $\left(\rho=0.685^{\star}\right)$ correlation with the dehydrogenase activity as a parameter for total aerobic microbial activity in composts [20]. $\beta$-glucosidase did not show any significant (at $\mathrm{p}=0.05$ ) correlation with microbial colonies. As suggested by [21] the significant component of the $\beta$-glucosidase activity is due to the stabilized extracellular enzyme fraction and is not directly associated with the extant microbial biomass. Strong positive correlation was observed between phosphodiesterase activity and mesophilic bacteria. This enzyme also showed a strong positive correlation with thermophilic fungi. The correlation results suggested that the synthesis of these hydrolyses were related to the growth of bacteria and fungi. The high correlation coefficients between urease activity and three groups of microbes including mesophilic bacteria, thermophilic bacteria and thermophilic fungi were observed as well, which proves that the activity of this enzyme influenced significantly by microbial population. The correlations between activities of the enzymes and different microbial colonies confirmed the presence of interrelationships among microbial species [18].

\section{Conclusion}

In this study, a composting experiment based on organic MSW was conducted. Dynamic changes in the diversity of microbial community and enzyme activities were observed, which proves that enzymatic activity and microbial population are important indicators for reflecting the microbiological properties of compost. Results implied that fluctuations in enzyme activities can be expected corresponding to the variations in microbial populations. The high enzyme activities, mesophilic bacteria, and fungi population at the later stage of composting confirmed that the degradation of substrate was ongoing after the bio-oxidative phase. The research findings provide a better understanding of the biodegradation process of organic MSW during a composting process. 


\section{References}

[1] Vargas-Garcia, M., Suárez-Estrella, F., Lopez, M. and Moreno, J. (2010) Microbial Population Dynamics and Enzyme Activities in Composting Processes with Different Starting Materials. Waste Management, 30, 771-778.

[2] Liu, D., Zhang, R., Wu, H., Xu, D., Tang, Z., Yu, G., et al. (2011) Changes in Biochemical and Microbiological Parameters during the Period of Rapid Composting of Dairy Manure with Rice Chaff. Bioresource Technology, 102, 9040-9049.

[3] Raut, M., Prince William, S., Bhattacharyya, J., Chakrabarti, T. and Devotta, S. (2008) Microbial Dynamics and Enzyme Activities during Rapid Composting of Municipal Solid Waste-A Compost Maturity Analysis Perspective. Bioresource Technology, 99, 6512-6519. https://doi.org/10.1016/j.biortech.2007.11.030

[4] Mondini, C., Fornasier, F. and Sinicco, T. (2004) Enzymatic Activity as a Parameter for the Characterization of the Composting Process. Soil Biology and Biochemistry, 36, 1587-1594. https://doi.org/10.1016/j.soilbio.2004.07.008

[5] Ryckeboer, J., Mergaert, J., Vaes, K., Klammer, S., De Clercq, D., Coosemans, J., et al. (2003) A Survey of Bacteria and Fungi Occurring during Composting and SelfHeating Processes. Annals of Microbiology, 53, 349-410.

[6] Ryckeboer, J., Mergaert, J., Coosemans, J., Deprins, K. and Swings, J. (2003) Microbiological Aspects of Biowaste during Composting in a Monitored Compost Bin. Journal of Applied Microbiology, 94, 127-137. https://doi.org/10.1046/j.1365-2672.2003.01800.x

[7] Delgado, A., Solera del Río, R., Sales, D. and García-Morales, J. (2004) Study of the Co-Composting Process of Municipal Solid Waste and Sewage Sludge: Stability and Maturity. Proceedings of the 11 th Conference of the FAO on Recycling of Agricultural Municipal and Industrial Residues in Agriculture, 257-260.

[8] Godden, B., Penninckx, M., Piérard, A. and Lannoye, R. (1983) Evolution of Enzyme Activities and Microbial Populations during Composting of Cattle Manure. Applied Microbiology and Biotechnology, 17, 306-310. https://doi.org/10.1007/BF00508026

[9] Thalmann, A. (1968) Zur Methodik der bestimmung der dehydrogenaseaktivität im boden mittels triphenyltetrazoliumchlorid (TTC). Landwirtsch. Forsch, 21, 249258.

[10] Alef, K. and Nannipieri, P. (1995) Methods in Applied Soil Microbiology and Biochemistry. Academic Press.

[11] Eivazi, F. and Tabatabai, M. (1988) Glucosidases and Galactosidases in Soils. Soil Biology and Biochemistry, 20, 601-606. https://doi.org/10.1016/0038-0717(88)90141-1

[12] Tabatabai, M.A. (1994) Soil Enzymes. In: Bottomley, P.S., Angle, J.S. and Weaver, R.W., Eds., Methods of Soil Analysis: Part 2-Microbiological and Biochemical Properties, Soil Science Society of America, Madison, WI, 775-833.

[13] Miyatake, F. and Iwabuchi, K. (2006) Effect of Compost Temperature on Oxygen Uptake Rate, Specific Growth Rate and Enzymatic Activity of Microorganisms in Dairy Cattle Manure. Bioresource Technology, 97, 961-965. https://doi.org/10.1016/j.biortech.2005.04.035

[14] Gómez, R.B., Lima, F.V. and Ferrer, A.S. (2006) The Use of Respiration Indices in the Composting Process: A Review. Waste Management \& Research, 24, 37-47. https://doi.org/10.1177/0734242X06062385

[15] Federici, E., Pepi, M., Esposito, A., Scargetta, S., Fidati, L., Gasperini, S., et al. (2011) 
Two-Phase Olive Mill Waste Composting: Community Dynamics and Functional Role of the Resident Microbiota. Bioresource Technology, 102, 10965-10972. https://doi.org/10.1016/j.biortech.2011.09.062

[16] Rashad, F.M., Saleh, W.D. and Moselhy, M.A. (2010) Bioconversion of Rice Straw and Certain Agro-Industrial Wastes to Amendments for Organic Farming Systems: 1. Composting, Quality, Stability and Maturity Indices. Bioresource Technology, 101, 5952-5960. https://doi.org/10.1016/j.biortech.2010.02.103

[17] de Bertoldi, M.D., Vallini, G.E. and Pera, A. (1983) The Biology of Composting: A Review. Waste Management \& Research, 1, 157-176. https://doi.org/10.1177/0734242X8300100118

[18] He, Y., Xie, K., Xu, P., Huang, X., Gu, W., Zhang, F., et al. (2013) Evolution of Microbial Community Diversity and Enzymatic Activity during Composting. Research in Microbiology, 164, 189-198. https://doi.org/10.1016/j.resmic.2012.11.001

[19] Barrena, R., Vázquez, F. and Sánchez, A. (2008) Dehydrogenase Activity as a Method for Monitoring the Composting Process. Bioresource Technology, 99, 905908. https://doi.org/10.1016/j.biortech.2007.01.027

[20] Benitez, E., Nogales, R., Elvira, C., Masciandaro, G. and Ceccanti, B. (1999) Enzyme Activities as Indicators of the Stabilization of Sewage Sludges Composting with Eisenia foetida. Bioresource Technology, 67, 297-303. https://doi.org/10.1016/S0960-8524(98)00117-5

[21] Garcia, C., Hernandez, T., Costa, F., Ceccanti, B. and Ciardi, C. (1992) Changes in ATP Content, Enzyme Activity and Inorganic Nitrogen Species during Composting of Organic Wastes. Canadian Journal of Soil Science, 72, 243-253. https://doi.org/10.4141/cjss92-023

\section{Submit or recommend next manuscript to SCIRP and we will provide best} service for you:

Accepting pre-submission inquiries through Email, Facebook, LinkedIn, Twitter, etc. A wide selection of journals (inclusive of 9 subjects, more than 200 journals)

Providing 24-hour high-quality service

User-friendly online submission system

Fair and swift peer-review system

Efficient typesetting and proofreading procedure

Display of the result of downloads and visits, as well as the number of cited articles Maximum dissemination of your research work

Submit your manuscript at: http://papersubmission.scirp.org/

Or contactwjet@scirp.org 